\title{
IAMJ
}

INTERNATIONAL

AYURVEDIC

MEDICAL JOURNAL

Research Article

ISSN: 23205091

Impact Factor: 5.344

\section{CROSS-SECTIONAL ASSESSMENT OF ASSOCIATION BETWEEN GRADE OF ASTHI SARATA AND INCIDENCE OF DENTAL CARIES}

\author{
Pathak Kshitiza $^{1}$, Pathak Akshay ${ }^{2}$ \\ ${ }^{1}$ Lecturer, Department of Roga Nidan, Govt. Ayurvedic College Patiala, Punjab, India \\ ${ }^{2}$ Lecturer, Department of Kriya Sharir, Govt. Ayurvedic College Patiala, Punjab, India
}

Corresponding Author: akshaypathak745@gmail.com

\section{https://doi.org/10.46607/iamj0108082020}

(Published online: August 2020)

Open Access

(C) International Ayurvedic Medical Journal, India 2020

Article Received: 10/07/2020 - Peer Reviewed: 29/07/2020 - Accepted for Publication: 04/08/2020

(D) Check for updates

\begin{abstract}
Dashavidha Karanadi Pariksha (Ten-fold examination) elaborated in Charaka Samhita imparts complete knowledge of patient's condition by means of specific investigations. It is done for knowledge of lifespan, degree of strength of body and disease and exact treatment perspective. Accordingly, a patient should be examined in respect of Dhatu Sarata (excellence of body tissues) i.e. as per the best qualities of Dhatu (body tissues). Drudh Danta (strongness of teeth) has been described as a characteristic of Asthi Sarata. Thus, an observational crosssectional study was planned to assess the probable association between gradation of Asthi Sarata (excellence of Asthi Dhatu-bone tissue) as Uttama (excellent) -Madhyama (moderate)-Heena (poor) and incidence of dental caries. Total 200 volunteers were assessed for their grade of Asthi sarata (excellence of Asthi Dhatu-bone tissue) with the help of a questionnaire related to general description of Asthi Sara Purusha (person with excellence of bone tissue) as per Charaka Samhita. Dental inspection of each participant was done to check for presence and absence of dental caries. The association between Sarata grade of each individual and incidence of dental caries was established by statistical analysis. Statistical tests showed that Asthi - Sarata (excellence of Asthi Dhatu-bone tissue) and occurrence of dental caries were dependent of each other.
\end{abstract}

Keywords: Asthi; Strong Teeth; Charaka; Dashavidha Pariksha 


\section{INTRODUCTION}

The Chikitsa or therapeutics in Ayurveda are of wholistic nature and care about all extrinsic and intrinsic aspects. In Rogabhishagjitiya Vimana chapter of Charaka Samhita, various methods of conquering debate as well as diseases have been described. Dashavidha Karanadi Parikshal (Ten-fold examination) elaborated here help the physician to get an upfront idea of entire situation by proper methods. It has been advocated that these ten entities must be examined first and thereafter proceed or initiate any treatment.

This ten-fold examination imparts complete knowledge of patient's condition by means of specific investigations. It is done for knowledge of lifespan, degree of strength of body and disease ${ }^{2}$. Also, this knowledge helps to determine the exact treatment perspective. The variations in dosage and potency of treatments varies as per disease state and degree of strength of patient. Hence, the patient should be examined in respect of constitution (Prakriti), morbidity (Vikriti), excellence of Dhatu (Sara), compactness (Samhanana), measurement (Pramana), suitability (Satmya), psyche (Sattva), power of intake and digestion of food (Aharashakti), power of exercise (Vyayamashakti) and age (Vaya) $)^{3}$.

Accordingly, a patient should be examined in respect of Sarata i.e. as per the best qualities of body tissues or Dhatu. There are eight types of Sarata described for the knowledge of degree of strength such as Tvak, Rakta, Mamsa, Meda, Asthi, Majja, Shukra and Sattva ${ }^{4}$.

A person with Asthi Sarata possesses well-defined heels (Parshni), ankles (Gulpha), knees (Janu), elbows (Aratni), collarbones (Jatru), chin (Chibuka), head (Shira), flanks (Parshva), overall joints (Sandhi) and also bones and teeth ${ }^{5}$. Such people are excessively enthusiastic, energetic, enduring, with strong and firm body as well as have a longer life span.

The persons possessing all these essences (Uttama Sarata) are very strong and happy, enduring etc., show slow ageing and pathogenic process and are long-lived. The individuals having moderate essence should be known by their respective qualities in mod- erate degrees (Madhyama Sarata). The individuals having only a few of these essences can be categorized under Heena Sarata.

Drudh Danta (strongness of teeth) has been described as a characteristic of Asthi Sarata. Danta or teeth are classified under Asthi (bones) in Ayurveda. It has also been elaborated that during the metabolism of Asthi Dhatu, Danta (teeth) are formed as their metabolic byproduct i.e. Updhatu ${ }^{6}$. Also, both Danta and Asthi are formed as Pitruja Bhava (body entities inherited from father) in foetal development ${ }^{7}$.

Thus, an observational cross-sectional study was planned to assess the probable association between gradation of Asthi Sarata (excellence of Asthi Dhatubone tissue) as Uttama (excellent) -Madhyama (moderate)-Heena (poor) and incidence of dental caries.

\section{Methodology-}

Total 200 volunteers were selected randomly in the age group 18 to 40 years (Both ages inclusive) irrespective of their gender and socio-economic status. Informed written consent of these participants was taken before any study related procedures.

Asthi sarata (excellence of Asthi Dhatu-bone tissue) was assessed with the help of a questionnaire related to general description of Asthi Sara Purusha (person with excellence of bone tissue) as per Charaka Samhita. The questionnaire captured grades of each characteristic as 0,1 and 2. The grades were added to get Asthi Sarata score. The score between 0-6 was considered as Heena Sara (Poor excellence), between 712 were considered as Madhyama Sara (moderate excellence) and between 13-18 were considered as Uttama Sara (excellent excellence).

Dental inspection of each subject was done to check for presence and absence of dental caries. The association between Sarata grade of each individual and incidence of dental caries were tabulated. The data were subjected to statistical analysis.

\section{Results-}

- Demographic Analysis-

1) Gender- Out of total 200 study subjects, 94 (47\%) were males while, 106 (53\%) were females. 
2) Diet-As the type of diet was concerned, 52 subjects $(26 \%)$ were vegetarian while 148 subjects
(74 \%) consumed mixed diet of vegetarian and non-vegetarian food.

Table 1: Response to questionnaire regarding characteristics of Asthi Sarata-

\begin{tabular}{|c|c|c|c|c|}
\hline Sr. No. & Characteristic of Asthi Sarata & Grade $0(\%)$ & Grade $1(\%)$ & Grade $2(\%)$ \\
\hline 1 & Mahotsaha (excess enthusiasm) & 11 & 64.5 & 24.5 \\
\hline 2 & Kriyavanta (very active) & 15 & 59 & 26 \\
\hline 3 & Kleshasaha (high endurance) & 0.5 & 67 & 27.5 \\
\hline 4 & Asthi Prominence (prominent bones) & 0 & 99.5 & 0.5 \\
\hline 5 & Chibuka Prominence (prominent chin) & 7.5 & 92 & 0.5 \\
\hline 6 & Sara Nakha (strong nails) & 6.5 & 89.5 & 4 \\
\hline 7 & Sara Sharira (strong body) & 0 & 91.5 & 8.5 \\
\hline 8 & Sthira Sharira (firmness of body) & 0.5 & 6 & 94 \\
\hline 9 & Drudha Danta-Asthi-Nakha (firm teeth, bones and nails) & 1.5 & 44 & 54.5 \\
\hline
\end{tabular}

Table 2: Gradation of Asthi Sarata-

\begin{tabular}{|l|l|l|l|}
\hline Sr. No. & Grade & Number of participants & Percentage \\
\hline 1 & Uttama (excellent) Sarata $(13-18)$ & 70 & $35 \%$ \\
\hline 3 & Madhyama (moderate) Sarata $(7-12)$ & 125 & $62.5 \%$ \\
\hline
\end{tabular}

Table 3: Assessment of dental caries

\begin{tabular}{|l|l|l|}
\hline Dental caries & Absent & Present \\
\hline Overall Percentage & $53 \%$ & $47 \%$ \\
\hline
\end{tabular}

Table 4: Association between gradation of Asthi Sarata and incidence of dental caries

\begin{tabular}{|l|l|l|l|l|l|}
\hline $\begin{array}{l}\text { Sr. } \\
\text { No. }\end{array}$ & Grade of Asthi Sarata & $\begin{array}{l}\text { Absence of dental } \\
\text { caries }\end{array}$ & $\begin{array}{l}\% \text { of Absence of } \\
\text { dental caries }\end{array}$ & $\begin{array}{l}\text { Presence of dental } \\
\text { caries }\end{array}$ & $\begin{array}{l}\% \text { of Presence of dental } \\
\text { caries }\end{array}$ \\
\hline 1 & Uttama (excellent) Sara & 45 & $64.2 \%$ & 25 & $35.7 \%$ \\
\hline 2 & Madhyama (moderate) Sara & 63 & $50.4 \%$ & 62 & $49.6 \%$ \\
\hline 3 & Heena (poor) Sara & 0 & $0 \%$ & 5 & $100 \%$ \\
\hline
\end{tabular}

Chi - Square test for independence was applied.

Null Hypothesis $\left(\mathbf{H}_{\mathbf{0}}\right)$ - There is no association between Asthi - Sarata and occurrence of dental caries. Or Asthi - Sarata and occurrence of dental caries are independent of each other.

Alternative Hypothesis $\left(\mathbf{H}_{1}\right)$ - There is an association between Asthi - Sarata and occurrence of dental caries. Or Asthi - Sarata and occurrence of dental caries are dependent of each other.

Chi - Square Value $=4.587$ (greater than table value 3.84 at 1 degree of freedom)

P Value $=0.0322$, Alternative Hypothesis $\left(\mathrm{H}_{1}\right)$ to be accepted.

\section{DISCUSSION}

The study was done to find out association of incidence of dental caries and gradation of Asthi Sarata (excellence of Asthi Dhatu-bone tissue) through an observational cross-sectional analysis. Statistical tests showed that Asthi - Sarata (excellence of Asthi Dhatu-bone tissue) and occurrence of dental caries were dependent of each other.

Dharana or support is the prime function of Asthi Dhatu. Asthi Dhatu also has an important role in maintenance of healthy status and provide immunity. Anivishta Mansa-Shonita-Asthi i.e. wholesome status of Mansa Dhatu, Rakta Dhatu and Asthi Dhatu is an important characteristic of desirous healthy body ${ }^{8}$. Thus, stability of Asthi Dhatu is important. The Sarata 
Parikshana (Examination of excellence of body tissues) helps to understand the immunity of the person. More the Sarata of Dhatu, more is the immunological strength of the person. Considering importance of $\mathrm{As}$ thi Dhatu, this study was planned.

Danta or teeth are important for aesthetics as well as body functions. Dental caries is a big concern in today's society due to faulty lifestyle. Still, not every individual is equally affected.

In the present study involving 200 participants, maximum participants showed characters of Madhyama Sarata (moderate excellence) of Asthi Dhatu; followed by Uttama Sara (excellent excellence) and Heena Sara (poor excellence). Dental caries was absent in majority of participants. Absence of dental caries was more pronounced in Uttama Sara (excellent excellence) individuals than Madhyama Sara (moderate excellence). All the participants with Heena Sarata (poor excellence) had dental caries. As the sampling technique was conventional sampling, no definite inferences could be drawn from demographic analysis.

Though dental caries is largely dependent on dental hygiene; nutritional status of body is also important ${ }^{9}$. As per Ayurveda principles, Dhatu Sarata and its gradation gives an outline about status of body in withstanding diseases or preventing them. Such studies give the physician a heads up in terms of impending risks.

The study had its limitations. It is recommended that it can be done with larger sample size and more robust objective assessment criteria. As no such study was done earlier, this study can act as a foundation in future.

\section{CONCLUSION}

It was concluded that, individuals with Uttama Sarata (excellent excellence) of Asthi Dhatu and Madhyama Sarata (moderate excellence) of Asthi Dhatu showed less incidence of dental caries as compared with Heena Asthi Sara (poor excellence) individuals. The statistical analysis also proved a definite correlation between gradation of Asthi Sarata of (excellence of Asthi Dhatu) and incidence of dental caries.

\section{REFERENCES}

1. Agnivesha, Charaka Samhita with Vidyotini Commentary, edited by Pt. Kashinath Shastri \& Dr. Gorakh Nath Chaturvedi, Published by- Chaukhambha Bharati Academy, Varanasi, Reprint Edition 2001; Vimana Sthana Ch:8-84, p. 767

2. Agnivesha, Charaka Samhita with Vidyotini Commentary, edited by Pt. Kashinath Shastri \& Dr. Gorakh Nath Chaturvedi, Published by- Chaukhambha Bharati Academy, Varanasi, Reprint Edition 2001; Vimana Sthana Ch:8-94, p. 771

3. Agnivesha, Charaka Samhita with Vidyotini Commentary, edited by Pt. Kashinath Shastri \& Dr. Gorakh Nath Chaturvedi, Published by- Chaukhambha Bharati Academy, Varanasi, Reprint Edition 2001; Vimana Sthana Ch:8-94, p. 767

4. Agnivesha, Charaka Samhita with Vidyotini Commentary, edited by Pt. Kashinath Shastri \& Dr. Gorakh Nath Chaturvedi, Published by- Chaukhambha Bharati Academy, Varanasi, Reprint Edition 2001; Vimana Sthana Ch:8-102, p. 775

5. Agnivesha, Charaka Samhita with Vidyotini Commentary, edited by Pt. Kashinath Shastri \& Dr. Gorakh Nath Chaturvedi, Published by- Chaukhambha Bharati Academy, Varanasi, Reprint Edition 2001; Vimana Sthana Ch:8-107, p. 776

6. Sharangadhara, Sharangadhara Samhita with Dipika commentary by Adhamalla, Chaukhamba Surbharati Prakashana, Varanasi, Edition-2004, Purva Khanda, 5page no. 38

7. Agnivesha, Charaka Samhita with Vidyotini Commentary, edited by Pt. Kashinath Shastri \& Dr. Gorakh Nath Chaturvedi, Published by- Chaukhambha Bharati Academy, Varanasi, Reprint Edition 2001; Sharira Sthana Ch:3-7, p. 856

8. Agnivesha, Charaka Samhita with Vidyotini Commentary, edited by Pt. Kashinath Shastri \& Dr. Gorakh Nath Chaturvedi, Published by- Chaukhambha Bharati Academy, Varanasi, Reprint Edition 2001; Sutra Sthana Ch:28-6, p. 570

9. J O Alvarez, Nutrition, tooth development, and dental caries, The American Journal of Clinical Nutrition, Volume 61, Issue 2, February 1995, Pages 410S416S, https://doi.org/10.1093/ajcn/61.2.410S

\section{Source of Support: Nil \\ Conflict of Interest: None Declared}

How to cite this URL: Pathak Kshitiza \& Pathak Akshay: Cross-Sectional Assessment Of Association Between Grade Of Asthi Sarata And Incidence Of Dental Caries. International Ayurvedic Medical Journal \{online\} 2020 \{cited August, 2020\} Available from: http://www.iamj.in/posts/images/upload/4032_4035.pdf 